\title{
Activation of the Orphan Nuclear Receptor ROR $\alpha$ Induces Growth Arrest in Androgen-Independent DU 145 Prostate Cancer Cells
}

\author{
Roberta M. Moretti, ${ }^{1}$ Marina Montagnani Marelli, ${ }^{1}$ Marcella Motta, ${ }^{1}$ Donatella \\ Polizzi, ${ }^{2}$ Silvia Monestiroli, ${ }^{2}$ Graziella Pratesi, ${ }^{2}$ and Patrizia Limonta ${ }^{1 *}$ \\ 'Center for Endocrinological Oncology, Department of Endocrinology, University of Milano, Milano, Italy \\ ${ }^{2}$ Department of Experimental Oncology B, National Cancer Institute of Milano, Milano, Italy
}

\begin{abstract}
BACKGROUND. ROR $\alpha$ is a transcription factor which belongs to the family of orphan nuclear receptors. The regulatory functions of this receptor are still poorly understood. However, response elements for $\mathrm{ROR} \alpha$ are present on the promoter of cell cycle-related genes suggesting that it might be involved in the control of cell proliferation. In this study, we investigated the expression and the possible function of $R O R \alpha$ in a human androgenindependent prostate cancer cell line (DU 145). The thiazolidinedione-derivative CGP 52608 has been utilized as the specific ligand and activator of ROR $\alpha$.

METHODS. The effects of CGP 52608 on DU 145 cell proliferation and cell cycle distribution were analyzed by hemocytometer and by FACS analysis, respectively. The expression of $\mathrm{ROR} \alpha$ as well as the effects of $\mathrm{ROR} \alpha$ activation on the expression of cell cycle-related genes were evaluated by RT-PCR. To clarify whether ROR $\alpha$ activation might affect the proliferation of prostate cancer cells also in vivo, nude mice bearing DU 145 tumor xenografts were treated with CGP 52608 at different doses and the growth of the tumors was followed by caliper measurement.

RESULTS. ROR $\alpha$ is expressed in DU 145 cells and the treatment of the cells with the thiazolidinedione-derivative CGP 52608 brought about a dose-dependent and significant decrease of cell proliferation. Ligand-induced activation of ROR $\alpha$ affected cell cycle distribution, inducing an accumulation in the $G_{0} / G_{1}$ phase and a decrease in the $S$ phase. This effect was accompanied by an increased expression of the cyclin-dependent kinase inhibitor p $21^{\mathrm{WAF} 1 / \mathrm{CIP} 1}$ and a decreased expression of cyclin A. The growth of DU 145 tumors in nude mice was significantly reduced by treatment with CGP 52608 .

CONCLUSIONS. These data indicate that, in androgen-independent DU 145 prostate cancer cells, activation of the orphan nuclear receptor ROR $\alpha$ inhibits cell growth, both in vitro and in vivo. ROR $\alpha$ also induces cell cycle arrest, possibly through the modulation of the expression of cell cycle-related genes. Prostate 46:327-335, 2001. (C) 2001 Wiley-Liss, Inc.
\end{abstract}

KEY WORDS: orphan nuclear receptors; prostate cancer; cell proliferation; cell cycle-related genes

\section{INTRODUCTION}

The importance of the development of new anticancer agents for the treatment of prostate carcinoma is highlighted by the continuous increase of the number of men diagnosed with this pathology. The tumor of the prostate is, actually, the most frequent malignancy and the second leading cause of male
Grant sponsors: Associazione Italiana per la Ricerca sul Cancro; Ministero della Ricerca Scientifica e Tecnologica.

*Correspondence to: Dr. Patrizia Limonta, Center for Endocrinological Oncology, Department of Endocrinology, University of Milano, Via Balzaretti 9, 20133 Milano, Italy.

E-mail: limonta@mailserver.unimi.it

Received 8 August 2000; Accepted 28 November 2000 
cancer deaths in the Western countries [1,2]. Prostate cancer is usually androgen-dependent in its early stages [3], when most patients positively respond to the suppression of testosterone secretion and/or action, which is mainly achieved through agonistic analogs of LHRH and antiandrogens, given either alone or in combination [3,4]. In later stages, after a given time of tumor remission, a new phase of growth appears in which surviving cancer cells have lost their androgen dependence. In this situation, prostate cancer hardly responds to conventional chemotherapy and, therefore, an effective treatment is still lacking [5].

Orphan nuclear receptors constitute a large subgroup of the superfamily of steroid/thyroid/vitamin $\mathrm{D} /$ retinoid receptors, for which no endogenous ligand has been identified so far. A novel subclass of orphan nuclear receptors is represented by the ROR $\alpha$ family of transcription factors, which comprises RZR (retinoid $Z$ receptor) $\alpha$, ROR (retinoid acid receptor-related orphan receptor) $\alpha 1,2$ and $3, \operatorname{RZR} \beta$, and ROR $\gamma$. Sequence alignment showed that $R Z R \alpha$ is an additional splicing variant of $R O R \alpha 1-3$, whereas $R Z R \beta$ and ROR $\gamma$ are encoded by different genes [6-8]. The four ROR $\alpha$ splicing variants share common DNA- and putative ligand-binding domains, but possess distinct aminoterminal domains [8]. They bind preferentially as monomers to a hormone-response element (RORE) composed of a 6-base pair AT-rich sequence preceding a half-site core motif PuGGTCA on the promoter of target genes $[7,8]$. ROR $\alpha$ has been shown to be expressed in many peripheral tissues and cells, such as liver, smooth muscle, testes, and peripheral blood lymphocytes [6]. This in contrast to RZR $\beta$, which has a brainspecific distribution [9], and to $\operatorname{ROR} \gamma$, which is mainly found in skeletal muscle [10].

Though ROR $\alpha$ is expressed in different tissues, its involvement in possible physiological functions is still poorly understood. The mutant mouse, staggerer, in which the ROR $\alpha$ gene is disrupted, exhibits cerebellar abnormalities, demonstrating the crucial role played by this receptor in the development of the cerebellum [11]. $\mathrm{ROR} \alpha$ has been suggested to be involved in lipid metabolism [12,13], to possess immunomodulatory activity [14], and to mediate the antiarthritic properties of a class of thiazolidinediones, of which CGP 52608 is the lead compound $[15,16]$. ROREs have been identified in the promoter region of cell cycle-related genes, such as those of the cyclin-dependent kinase (CDK) inhibitor p21 ${ }^{\text {WAF1/CIP1 }}[13]$ and of cyclin A (Dr. C. Carlberg, Dusseldorf, Germany, personal communication), as well as in the promoter of N-myc [17], a gene whose amplification appears to be related to the development of several tumors [18-20]. Taken together, these observations suggest that the transcription factor might be involved in the regulation of cell growth and differentiation. In support of this observation, it has recently been reported that ligand-induced activation of ROR $\alpha$ significantly reduces the growth of the murine colon 38 adenocarcinoma [21].

In this study, we have investigated the expression and the possible function of ROR $\alpha$ in the proliferation of a human androgen-independent prostate cancer cell line (DU 145).

\section{MATERIALS AND METHODS}

\section{Materials}

The thiazolidinedione derivative CGP 52608 was kindly donated by Dr. I. Wiesenberg (Novartis, Basel, Switzerland). This compound has been previously demonstrated to specifically bind and activate $\mathrm{ROR} \alpha$ $[15,16]$.

\section{Cell Culture and Proliferation Studies}

The prostate cancer DU 145 cell line was obtained from American Type Culture Collection (Rockville, MD). DU 145 cells were routinely grown in RPMI-1640 medium (Seromed Biochrom, Berlin, Germany) supplemented with 5\% FBS (Gibco, Paisley, Scotland, UK), glutamine $(1 \mathrm{mM})$ and antibiotics (100 units $/ \mathrm{ml}$ penicillin G sodium, $100 \mu \mathrm{g} / \mathrm{ml}$ streptomycin sulphate) in a humidified atmosphere of $5 \% \mathrm{CO}_{2} / 95 \%$ air. For proliferation studies, DU 145 cells were treated with CGP 52608 (from 0.01 to $1000 \mathrm{nM}$ ) for 7 days. At the end of the treatment, cells were harvested and counted by hemocytometer.

\section{RT-PCR for ROR $\alpha$}

In order to determine whether ROR $\alpha$ receptors are expressed in prostate cancer cells, RT-PCR was performed on RNA extracts from DU 145 cells. After phenol-chloroform extraction, $1 \mu \mathrm{g}$ of total RNA from each sample was used in a reverse transcription reaction. cDNA synthesis was performed using the Gene AMP kit (Perkin Elmer Cetus, Norwalk, CT), with an oligo $(\mathrm{dT})_{16}$ as a primer for the reverse transcriptase. Samples containing cDNAs were then amplified in a $100 \mu \mathrm{l}$ solution containing PCR buffer $(50 \mathrm{mM} \mathrm{KCl}$, $10 \mathrm{mM}$ Tris- $\mathrm{HCl}$ ), $2 \mathrm{mM} \mathrm{MgCl} 2,15$ pmol of a pair of specific primers and $2.5 \mathrm{U}$ Taq Polymerase. Thirty-five cycles of amplification were performed in a programmable heat block (Perkin Elmer Cetus) (1-min denaturation at $94^{\circ} \mathrm{C}, 45$-sec primer annealing at $45^{\circ} \mathrm{C}$, and 2-min primer extension at $72^{\circ} \mathrm{C}$ ). The primers were: 5'-AACGGCGAGACTTCCCCAACTG-3' (sense, 637658) and 5'-CAAAGGCACGGCACACTCTGATAA-3' (antisense, 950-973) [22]. After RT-PCR, the amplified DNA products were separated on a $1.5 \%$ agarose gel and stained with ethidium bromide. Southern blot 
analysis was performed and the blots were hybridized with a synthetic ${ }^{32} \mathrm{P}$-labeled oligonucleotide probe: 5'-GGGAGCTGATGTGGCAATTG-3' (803-822).

\section{FACS Analysis}

Fluorescence-activated cell sorting (FACS) analysis was performed as described [23]. DU 145 cells were plated at a density of 400 cells $/ \mathrm{cm}^{2}$ in $100-\mathrm{mm}$ dishes in RPMI-1640 supplemented with 5\% FBS. Twentyfour hours after plating, the cells were treated either with vehicle or with CGP 52608 (1 and $100 \mathrm{nM}$ ) for $48 \mathrm{hr}$. After the treatment, DU 145 cells were trypsinized, washed twice with ice-cold PBS, fixed by drop-wise addition of $70 \%$ ethanol and incubated at $4^{\circ} \mathrm{C}$ overnight with constant agitation. Thirty minutes before flow cytometric analysis, the cellular doublestranded nucleic acids were stained with propidium iodine $(50 \mu \mathrm{g} / \mathrm{ml})$. RNAse (100 units $/ \mathrm{ml})$ was included to degrade double-stranded RNA. Propidium iodine fluorescence was obtained using linear amplification with doublet discrimination. Five thousand forward scatter gated events were collected per sample. Data were analyzed by the Cellquest program (Becton-Dickinson, San Jose, CA).

\section{RT-PCR for p2I ${ }^{\text {WAFI/CIPI }}$ and for Cyclin A}

In preliminary experiments, RT-PCR was utilized to verify the expression of the mRNAs for p21 WAF1/CIP1, cyclin A and $\beta$-actin (as an internal standard) in DU 145 cells. Extraction of total RNA from DU 145 cells and RT-PCR were conducted as previously described for $R O R \alpha$ expression. Primers were as follows: p21 ${ }^{\text {WAF1/CIP1 }}$ sense 5'-GTGAGCGATGGAACTTCGA-3' ${ }^{\prime}$ and antisense $5^{\prime}$-AATCTGTCATGCTGGTCTGC$3^{\prime}$ [24]; cyclin A sense 5'-ATTAGTTTACCTGGACCCAG-3' and antisense 5'-CACAAACTCTGCTACTTCTG-3' [25]; $\beta$-actin sense 5'-TGACGGGGTCACCCACACTGTGCCCATCTA- $3^{\prime}$ and antisense 5'-CTAGAAGCATTTGCGGTGGACGATGGAGGG-3' [26]. PCR amplification was performed for 35 cycles (1-min denaturation at $94^{\circ} \mathrm{C}, 45$-sec primer annealing at $60^{\circ} \mathrm{C}$ and 2-min primer extension at $72^{\circ} \mathrm{C}$ ). cDNA products were separated on $1.5 \%$ agarose gel and stained with ethidium bromide. To confirm the specificity of the cDNAs obtained, RT-PCR products were Southern blotted and the blots were hybridized with ${ }^{32} \mathrm{P}$-labeled oligonucleotide probes, specific for the cDNA sequences of $\mathrm{p} 21^{\mathrm{WAF} 1 / \mathrm{CIP} 1}$, cyclin $\mathrm{A}$, and $\beta$-actin, respectively.

To choose the adequate number of cycles for the amplification of $\mathrm{p} 21^{\mathrm{WAF} 1 / \mathrm{CIP} 1}$, cyclin $\mathrm{A}$, and $\beta$-actin cDNAs, we performed RT-PCR on RNA extracted from DU 145 cells using different numbers of cycles: from 20 to 35 . After RT-PCR, the amplified
cDNAs were separated on an agarose gel, stained with ethidium bromide, and photographed under UV light.

To study the effects of ligand-induced activation of $\mathrm{ROR} \alpha$ on the expression of cell cycle-related genes, DU 145 cells were plated in $100 \mathrm{~mm}$ dishes at a density of 15,000 cells $/ \mathrm{cm}^{2}$. Twenty-four hours after plating, the cells were treated with CGP 52608 (either 1 or $100 \mathrm{nM}$ ) for $3,6,12,24$ or $36 \mathrm{hr}$. At the end of the treatment, the cells were harvested, RNAs were extracted, and submitted to RT-PCR at adequate cycles. Equal RT reaction solutions were utilized in the PCR reaction in the presence of the specific primers for $\mathrm{p} 21^{\mathrm{WAF} 1 / \mathrm{CIP} 1}$, cyclin A, and $\beta$-actin. After RT-PCR, the relative intensities of the cDNA bands were quantitated by computer-assisted densitometric scanning using the Image program, and $\mathrm{p} 21^{\mathrm{WAF} 1 / \mathrm{CIP} 1}$ and cyclin A cDNA levels were standardized to $\beta$-actin cDNAs at the corresponding time intervals.

\section{Tumor Growth Studies}

Experiments were carried out using male athymic CD1 nude mice, 9 weeks old (Charles River, Calco, Italy). Animals were maintained in laminar flow rooms, keeping temperature and humidity constant. Experimental protocols were approved by the Ethic Committee for Animal Experimentation of the National Cancer Institute (Milano, Italy) according to the U.K. Coordinating Committee on Cancer Research Guidelines [27]. DU 145 cells were inoculated subcutaneously from in vitro cell cultures $\left(8 \times 10^{6} / 0.2 \mathrm{ml}\right.$ medium/flank). In all the experiments performed, injection of the cells resulted in rapidly growing tumors in $100 \%$ of animals. Each control or drug-treated group included five/six mice bearing bilateral tumors. CGP 52608 was formulated at different concentrations (from 0.01 to $10 \mathrm{mg} / \mathrm{kg}$ ) by suspending it in an aqueous solution of $0.5 \%$ methylcellulose/ $\mathrm{EtOH} 5 \%$. The formulated solution was made fresh every 2-3 days and administered daily per os (by gavage) in a volume of $10 \mathrm{ml} / \mathrm{kg}$ body weight; control animals were treated with solvent. This protocol is similar to the one used by Dr. Wiesenberg and coworkers [16] to evaluate the antiarthritic properties of CGP 52608. Tumor growth was followed by assessing tumor volume: width ${ }^{2} \times$ length $/ 2$, every 3-4 days over the experimental frame. Mice were weighed twice a week and their general health was monitored during the entire experiment.

\section{Experiment I}

Mice were inoculated with DU 145 cells and drug treatment was started on the same day of inoculum (Day 0) and continued with a daily schedule for 2 weeks. The growth of tumors was followed by 
caliper measurement at different time intervals up to 18 days.

\section{Experiment 2}

Animals were inoculated with DU 145 cells (Day 0) and CGP 52608 treatment $(0.01-10 \mathrm{mg} / \mathrm{kg})$ started 7 days after implantation (when tumors reached approximately $80-90 \mathrm{~mm}^{3}$ in volume) and continued up to Day 23 after cell inoculation with a daily schedule. In this experiment, one mouse/group was sacrificed by cervical dislocation on days 16 and 23; the tumors were collected and processed for histological examination. Samples were stained with hematoxylin and eosin and evaluated by light microscopy for the degree of inflammation and necrosis and for the evaluation of apoptotic and mitotic cells.

\section{Statistical Analysis}

Statistical comparisons of the data were performed using the Dunnett test [28] after one-way analysis of variance.

\section{RESULTS}

\section{Expression of ROR $\alpha$ in DU 145 Cells}

RT-PCR experiments demonstrated that the nuclear orphan receptor $\mathrm{ROR} \alpha$ is expressed in DU 145 cells, since the predicted 337-bp cDNA fragment hybridized with a specific ${ }^{32} \mathrm{P}$-labeled oligonucleotide probe (Fig. 1A, lane 1). The cDNA fragment was not seen in reactions in which the reverse transcriptase was omitted (Fig. 1A, lane 2).

\section{Effects of ROR $\alpha$ Activation on DU 145 Cell Proliferation}

We investigated whether the ligand-induced activation of $\operatorname{ROR} \alpha$ might affect the proliferation of DU 145 cells. Exponentially growing DU 145 cells were treated daily, for 7 days, with different doses of CGP 52608. The treatment brought about a significant and dose-dependent decrease of tumor cell proliferation (Fig. 1B). The thiazolidinedione derivative was significantly $(P<0.05$ ) effective from 0.1 to $1000 \mathrm{nM}$, with a half-maximal response at approximately $5 \mathrm{nM}$.

\section{Effects of ROR $\alpha$ Activation on Cell Cycle Distribution of DU 145 Cells}

To investigate the possible mechanisms underlying the antiproliferative effect related to $\mathrm{ROR} \alpha$ activation, we first assessed the effects of CGP 52608 (1 and $100 \mathrm{nM}$ ) on cell cycle distribution. FACS analysis indicated that both doses of CGP 52608 caused a significant $(P<0.05)$ and dose-dependent accumulation of
A

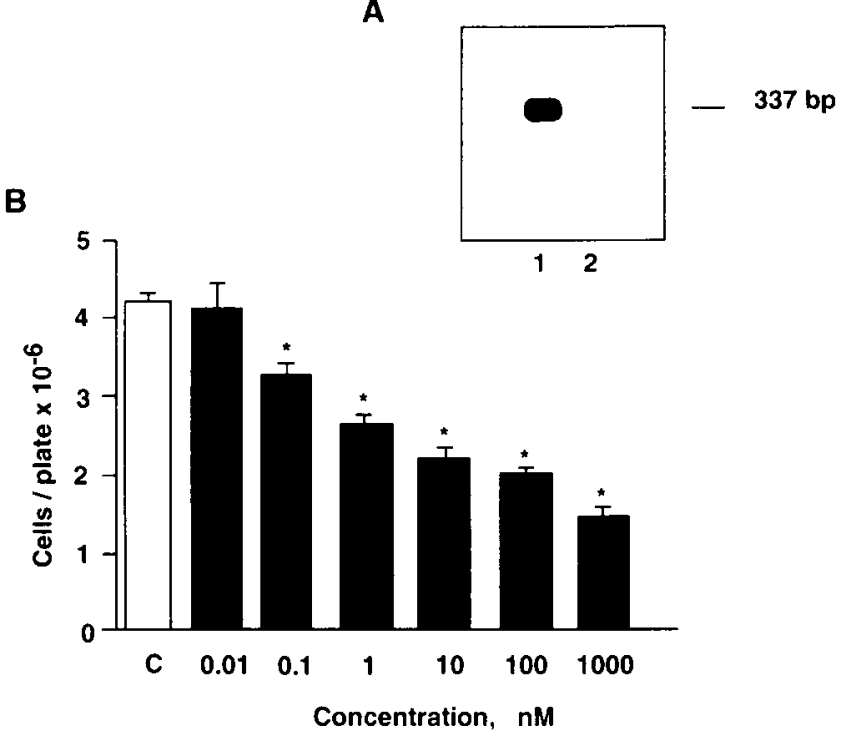

Fig. I. ROR $\alpha$ is expressed in DU I45 cells and its activation results in reduced cell proliferation. (A) RT-PCR analysis of $R Z R / R O R \alpha$ expression in DU 145 cells. Total RNA from DU 145 cells was reverse-transcribed and amplfied by PCR in the presence of specific oligonucleotide primers. After Southern blot, the 337 bp cDNA fragment obtained specifically hybridized with the ${ }^{32} \mathrm{P}$-labeled ROR $\alpha$ oligonucleotide probe (lane I). Lane 2, no reverse transcription. (B) Inhibition of DU 145 cell growth by different doses of CGP 52608. Data are expressed as the mean cell number/plate \pm SEM. $P<0.05$ vs. Controls, $C$.

the cell populations in the $G_{0} / G_{1}$ phase of the cell cycle and a decrease in $S$ phase (Table I). Lower doses of the compound were found to be ineffective (data not shown). These experiments demonstrate that activation of ROR $\alpha$ leads to cell cycle withdrawal in DU 145 cells.

\section{Effects of ROR $\alpha$ Activation on p2 ${ }^{\text {WAFI/CIPI }}$ and Cyclin A Expression in DU 145 Cells}

Since CGP 52608 significantly affects the distribution of DU 145 cells through the cell cycle, we investigated whether $\operatorname{ROR} \alpha$ activation might modulate the expression of cell cycle-related genes, such as

TABLE I. Effects of CGP 52608 on Cell Cycle Distribution of DU 145 Cells

\begin{tabular}{lccr}
\hline & Controls & $\begin{array}{c}\text { CGP 52608 } \\
1 \mathrm{nM}\end{array}$ & $\begin{array}{c}\text { CGP 52608 } \\
100 \mathrm{nM}\end{array}$ \\
\hline $\mathrm{G}_{0} / \mathrm{G}_{1}$ & $48.2 \pm 1.1$ & $56.2 \pm 1.0^{*}$ & $65.7 \pm 1.8^{*}$ \\
$\mathrm{~S}$ & $22.3 \pm 0.2$ & $16.4 \pm 0.7^{*}$ & $9.6 \pm 0.6^{*}$ \\
$\mathrm{G}_{2} / \mathrm{M}$ & $28.4 \pm 1.3$ & $27.8 \pm 0.9$ & $31.1 \pm 0.4$ \\
\hline
\end{tabular}

${ }^{*} P<0.05$ vs. controls. 


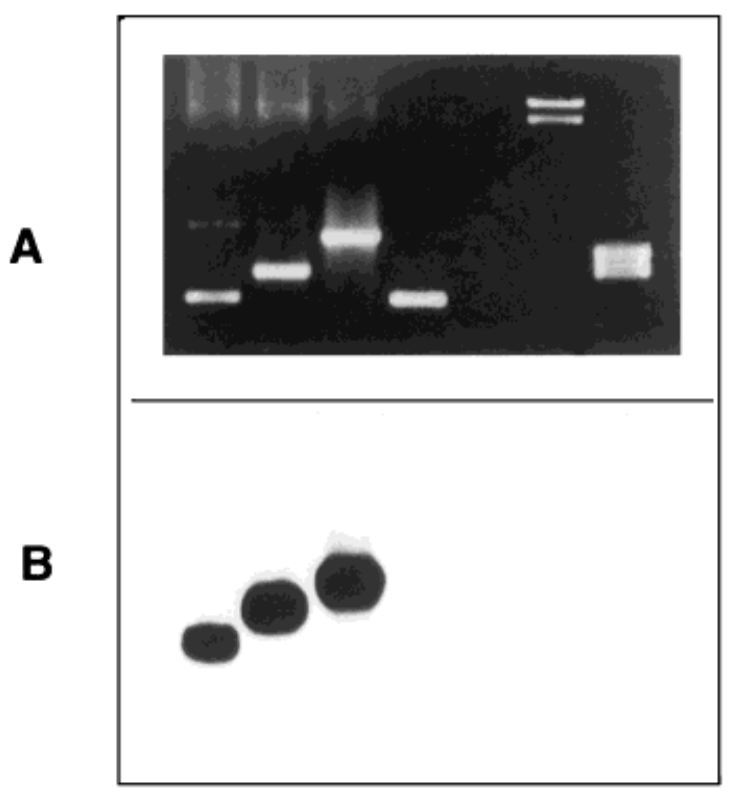

\section{$\begin{array}{lllllll}1 & 2 & 3 & 4 & 5 & 6 & 7\end{array}$}

Fig. 2. Expression of $\left.p 2\right|^{\mathrm{WAF} / \mathrm{CIPI}}$, cyclin A, and $\beta$-actin in DU 145 cells. Total RNA from DU 145 cells was reverse-transcribed and amplified by PCR in the presence of specific oligonucleotide primers. (A) Ethidium bromide stained agarose gel of the amplified cDNAs. (B) Autoradiography of the Southern blot obtained from the gel shown in $(A)$ after hybridization with specific ${ }^{32} \mathrm{P}$-labeled oligonucleotide probes. Lane I, $\mathrm{P}^{\mathrm{WAFI} / \mathrm{CIPI}}$; lane 2, cyclin A; lane 3, $\beta$-actin; lane 4, RT-PCR control (308 bp); lane 5, no reverse transcriptase; lanes $\mathbf{6}$ and 7, DNA molecular weight markers III and V, respectively (Roche Diagnostic, Monza, Italy).

p21 $1^{\mathrm{WAF} 1 / \mathrm{CIP} 1}$ and cyclin A. As already mentioned, in the promoter of these genes a RORE has been previously identified.

In preliminary experiments, we performed RT-PCR analysis in the presence of specific oligonucleotide primers for $\mathrm{p} 21^{\mathrm{WAF} 1 / \mathrm{CIP} 1}$, for cyclin $\mathrm{A}$, and for $\beta$-actin (as an internal standard). As expected according to the primers used, cDNA products of 311, 443, and $660 \mathrm{bp}$ were obtained for the three genes, respectively (Fig. 2A). After Southern blotting, the cDNA bands hybridized with ${ }^{32}$ P-labeled oligonucleotide probes, confirming the specificity of the amplified cDNAs (Fig. 2B ).

We then conducted RT-PCR at various cycles to choose the adequate number of cycles for each gene. The intensity of each band increased in parallel with the increasing number of PCR cycles, as shown in Figure 3. We concluded that the adequate number of PCR cycles for $\mathrm{p} 21^{\mathrm{WAF} 1 / \mathrm{CIP} 1}$ and for $\beta$-actin was 20 and that for cyclin A was 25.

To study the effects of $R O R \alpha$ activation on the expression of cell cycle-related genes, DU 145 cells

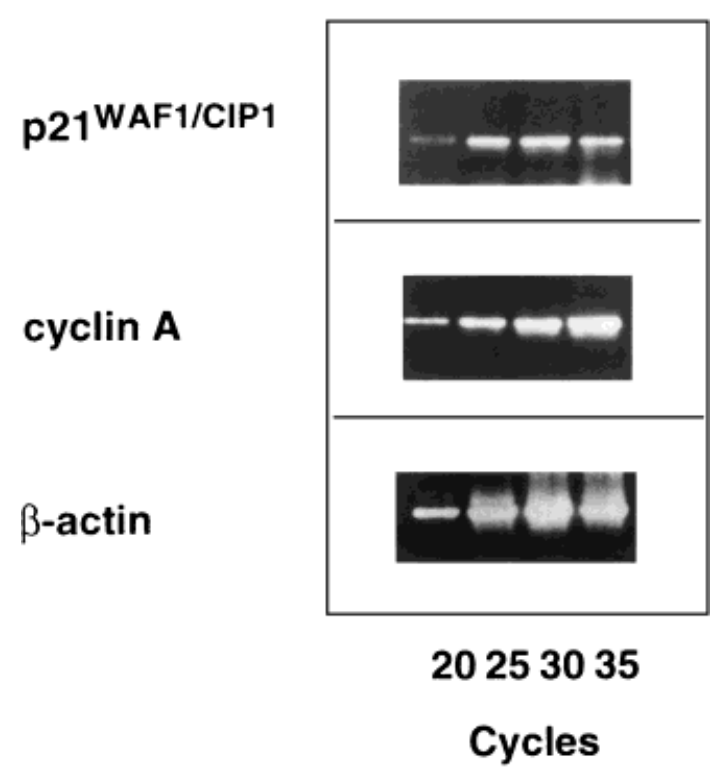

Fig. 3. Intensities of PCR products for $\left.P 2\right|^{W A F I / C I P I}$, cyclin $A$, and $\beta$-actin at various cycles. PCR amplifications were conducted at various cycles starting with equal RT reaction solutions.

were treated with CGP 52608 ( 1 and $100 \mathrm{nM}$ ) for different time intervals, from 3 to $36 \mathrm{hr}$. At the end of the treatment, RT-PCR was performed on extracted RNAs at adequate cycles. We found that, in control cells, p21 $21^{\mathrm{WAF} 1 / \mathrm{CIP} 1}$ mRNA expression was slightly expressed at all time intervals (Fig. 4A). CGP 52608, at both doses, significantly $(P<0.05)$ increased p21 ${ }^{\mathrm{WAF} 1 / \mathrm{CIP} 1}$ mRNA levels at $6 \mathrm{hr}$ (Figs. 4A, 5A). In the absence of CGP 52608, cyclin A mRNA levels remained at the basal level until $3 \mathrm{hr}$, but markedly increased thereafter (Fig. 4B). The thiazolidinedione derivative significantly $(P<0.05)$ inhibited cyclin A mRNA expression at 24 and $36 \mathrm{hr}$ after plating (Figs. $4 \mathrm{~B}, 5 \mathrm{~B})$. As expected, the levels of $\beta$-actin mRNA were not affected by the treatment at any time interval considered (Fig. 4C).

\section{Effects of ROR $\alpha$ Activation on DU 145 Tumor Growth in Nude Mice}

We investigated whether the activation of $\operatorname{ROR} \alpha$ could affect the growth of prostate cancer cells also in an in vivo setting.

In the first experiment, DU 145 cells were injected subcutaneously into the flank of nude mice and the treatment with CGP $52608(0.01-10 \mathrm{mg} / \mathrm{kg}$, daily by gavage) was started the same day. Tumor volume was measured at different time intervals, up to Day 18. A significant reduction in tumor volume was detectable in mice treated with CGP 52608, at any dose, by Day 7 up to Day 11 (Fig. 6A). At these time intervals, the 
Oh $3 \mathrm{~h} 6 \mathrm{~h} \quad 12 \mathrm{~h} 24 \mathrm{~h} 36 \mathrm{~h}$

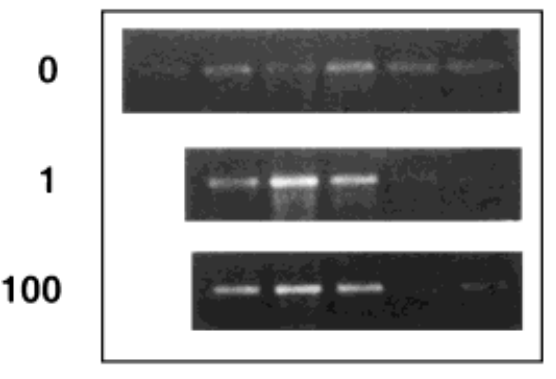

A 0h 3h 6h 12h 24h $36 \mathrm{~h}$

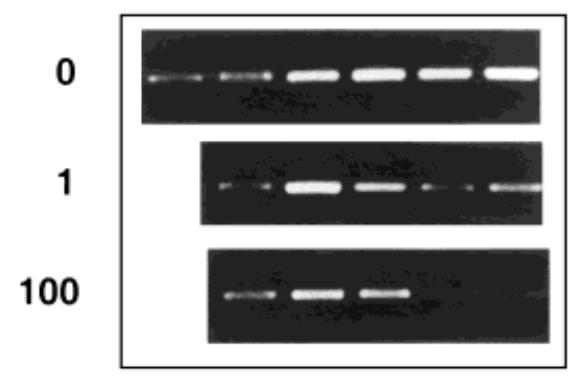

B

Oh $3 \mathrm{~h} 6 \mathrm{~h} 12 \mathrm{~h} 24 \mathrm{~h} 36 \mathrm{~h}$

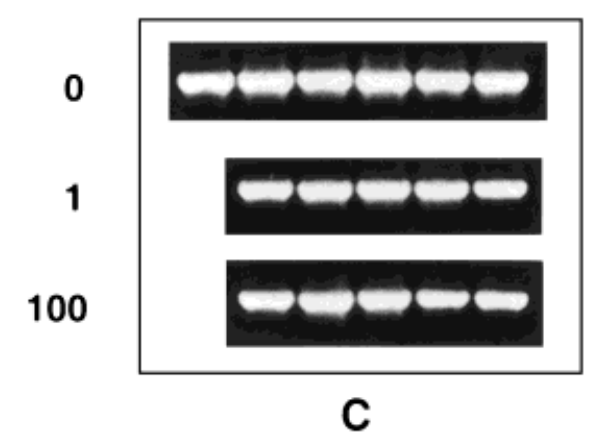

Fig. 4. Effects of ROR $\alpha$ activation on cell cycle-related gene expression in DU 145 cells. Cells were treated with CGP 52608 (I nM, middle lane, and $100 \mathrm{nM}$, lower lane) or with vehicle alone (upper lane). Total RNA was extracted at the indicated times and analyzed by RT-PCR at adequate cycles as described in 'Materials and Methods' for $\mathrm{p} 2 \mathrm{I}^{\mathrm{WAFI} / \mathrm{CIPI}}$ (A), cyclin A (B) and, $\beta$-actin (C).

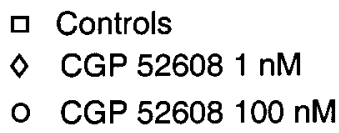

A

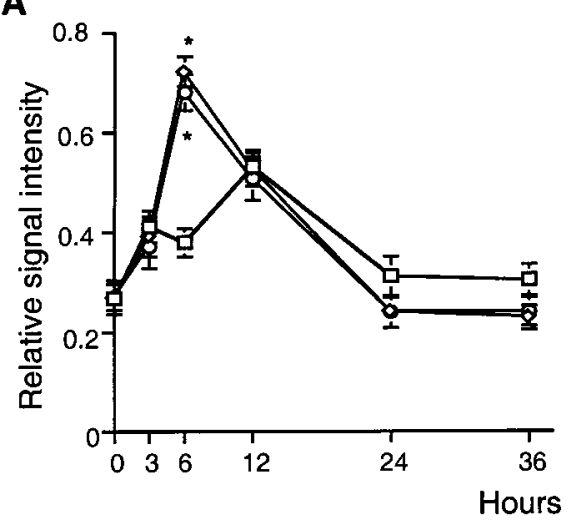

B

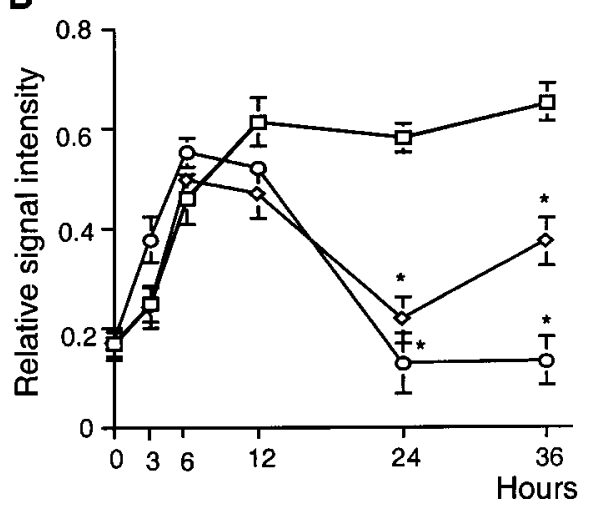

Fig. 5. Quantitative analysis of the effects of ROR $\alpha$ activation on cell cycle-related gene expression in DU 145 cells. Relative intensities of the bands shown in Fig. 4 were quantitated by computer-assisted densitometric scanning using the Image program, and p 2 I $^{\mathrm{WAFl} / \mathrm{CIPI}}$ (A) and cyclin A (B) cDNA levels were standardized to $\beta$-actin cDNAs at the corresponding time intervals. $P<0.05$ vs. Controls at corresponding time intervals. 


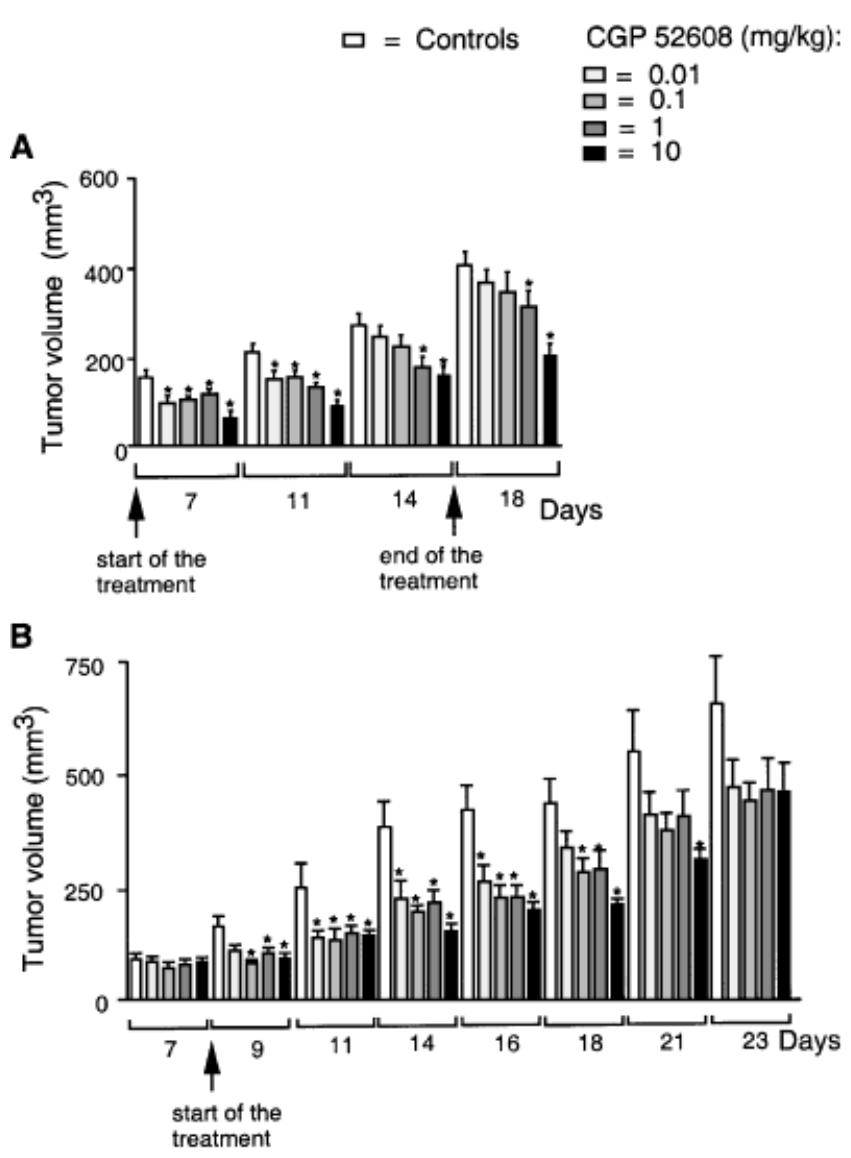

Fig. 6. Effects of the ROR $\alpha$ ligand on the growth rate of DU 145 tumors in nude mice. Animals were treated daily, by gavage, with CGP 52608 at different doses. Data are expressed as the mean tumor volume \pm SEM. (A) Treatment was started simultaneously with cell inoculation and lasted up to Day 14. (B) Treatment was started 7 days after cell inoculation and lasted up to Day 23. $P<0.05$ vs. Controls at corresponding time intervals.

average tumor volume in CGP 52608-treated mice was approximately $50 \%$ of that found in control mice. The highest doses ( 1 and $10 \mathrm{mg} / \mathrm{kg}$ ) were found to be effective at later intervals also (Fig. 6A).

In the second experiment, DU 145 cells were injected subcutaneously into nude mice on Day 0, but the treatment $(0.01-10 \mathrm{mg} / \mathrm{kg}$, daily, by gavage) was started only 7 days later, when the tumors were already present $(80-90 \mathrm{mg})$. The treatment lasted up to Day 23. Figure $6 \mathrm{~B}$ shows that a significant reduction in tumor volume was detectable up to Day 16, at all the doses of CGP 52608 used. After this time interval, the treatment was significant on Day 18 at the doses of $0.1-10 \mathrm{mg} / \mathrm{kg}$ and on Day 21 at the dose of $10 \mathrm{mg} / \mathrm{kg}$ (Fig. 6B). However, tumor volumes in treated animals remained always lower than in control mice even if not significantly, possibly due to the high variability of tumor volumes at longer time intervals (Fig. 6B).
Histological examination of the tumors by light microscopy revealed a comparable level of inflammation and necrosis in control and treated tumors. Moreover, no sign of toxicity (as detected by body, spleen, liver, lungs, seminal vesicles, and prostate weights) was associated with CGP 52608 treatment (data not shown).

\section{DISCUSSION}

In this study we have shown that $\mathrm{ROR} \alpha$ is expressed in androgen-independent DU 145 prostate cancer cells and that its ligand-induced activation brings about a significant decrease in cell proliferation and tumor growth. We have also shown that CGP 52608, the specific ligand and activator of $R O R \alpha$, induces cell cycle withdrawal by accumulating cells in the $G_{0} / G_{1}$ phase, and decreasing cells in the S phase.

Cell cycle arrest is obviously the result of a modification of the expression and/or activity of factors which play a crucial role in cell cycle progression. It is known that progression through the cell cycle is governed by a family of cyclins/CDKs complexes. Each CDK can form binary complexes with several cyclins and various cyclin/CDK complexes regulate a distinct phase of the cell cycle [29]. Cyclin D1, by complexing with CDK4, stimulates progression from $\mathrm{G}_{1}$ to $\mathrm{S}$; the activity of this complex is blocked by the CDK inhibitor p21 WAF1/CIP1 [29]. Cyclin A, which starts being synthesized at the end of $\mathrm{G}_{1}$ phase, appears abundantly at the $G_{1} / S$ transition, and triggers the $S$ phase $[29,30]$. Our data have shown that CGP 52608 , by activating the ROR $\alpha$ receptor, increases the expression of $\mathrm{p} 21^{\mathrm{WAF} 1 / \mathrm{CIP} 1}$, thus blocking $\mathrm{G}_{1} / \mathrm{S}$ progression, and decreases the expression of cyclin $\mathrm{A}$, thus preventing the triggering of $\mathrm{S}$ phase. Therefore, $R O R \alpha$ activation in androgen-independent prostate cancer cells seems to lead to growth arrest and to cell cycle withdrawal, at least partially, through a modulation of the expression of genes which are deeply involved in the regulation of the cell cycle.

The molecular mechanisms through which ROR $\alpha$ might modulate the expression of $\mathrm{p} 21^{\mathrm{WAF} 1 / \mathrm{CIP} 1}$ and cyclin A are still unknown. As already mentioned, this receptor has been shown to bind preferentially as a monomer to a RORE composed of a AT-rich sequence preceding a half-site core motif PuGGTCA in the promoter region of target genes $[7,8]$. Since this hexameric consensus motif is recognized by most of the nuclear receptors, it has been suggested that $\operatorname{ROR} \alpha$ might regulate its target genes by competing with other transcription factors, such as retinoid receptors, COUP-TF, and PPAR for binding to DNA [13,31]. In line with this observation, ROR $\alpha$ has recently been shown to increase the transcriptional activity of the thyroid hormone 
receptor [32]. Whether ROR $\alpha$ might affect the expression of $\mathrm{p} 21^{\mathrm{WAF} 1 / \mathrm{CIP} 1}$ and cyclin A through interaction with other transcription factors is still an open question.

The conclusion that $\mathrm{ROR} \alpha$ activation induces growth arrest in androgen-independent DU 145 prostate cancer cells is further supported by in vivo studies. We have shown that the thiazolidinedione derivative CGP 52608 exerts a significant dose-dependent growth inhibition of DU 145 prostate cancer xenografts in nude mice. A comparable response was achieved treating early (Day 0) or advanced (Day 7) tumors, possibly reflecting the cytostatic effect of the receptor ligand. Our results are in line with the data previously reported for a colon cancer cell line. As mentioned in the Introduction, Karasek et al. [21] have actually shown that the treatment of CGP 52608 inhibits the growth of the murine Colon 38 adenocarcinoma, both in vitro and in vivo. These observations, together with our data, seem to suggest that activation of $\mathrm{ROR} \alpha$ might be considered as the possible molecular basis for the cytostatic activity of new anticancer agents. Combinations between cytostatic and cytotoxic agents are currently under study in clinical settings due to the encouraging results obtained in preclinical models [33]. Therefore, a possible combination of compounds activating $\mathrm{ROR} \alpha$ with classical cytotoxic chemotherapy to optimize the efficacy of the treatment is worth being investigated. Interestingly, this nuclear receptor has been reported to interact with the metastasis suppressor candidate NM23 [34], suggesting that it might be involved not only in the control of cancer cell proliferation, but also in the regulation of their metastatic potential. Studies are in progress in our laboratory to verify this hypothesis.

On the basis of their deep involvement in important cellular mechanisms, the identification of specific ligands for orphan nuclear receptors represents a crucial step in the identification of their physiological functions. So far, no endogenous ligands for ROR $\alpha$ have been definitely identified. Melatonin, the major pineal gland hormone, which seems to possess oncostatic properties, has been shown to bind and activate ROR $\alpha$, when transiently transfected in Drosophila cells [9,35]. Moreover, Garcia-Maurino and coworkers have shown that CGP 52608 can displace the binding of ${ }^{125} \mathrm{I}-$ melatonin to nuclear extracts of human lymphocytes [14]. However, the possibility that the pineal gland hormone might represent the endogenous ligand for this class of receptors is still a matter of debate $[9,36]$.

In conclusion, ligand-induced activation of $\operatorname{ROR} \alpha$, plays a critical role in the control of the growth of hormone-independent DU 145 prostate cancer cells, either in in vitro or in in vivo systems.

\section{ACKNOWLEDGMENTS}

We thank Dr. I. Wiesenberg (Novartis, Basel, Switzerland) for her generous gift of CGP 52608 and Dr. C. Carlberg (Heinrich-Heine-Universitaet, Dusseldorf, Germany) for critically reviewing the manuscript.

\section{REFERENCES}

1. Parker SL, Tong T, Bolden S, Winger PA. Cancer statistics 1997. CA Cancer J Clin 1997;47:5-27.

2. Ruijter E, Van De Kaa C, Miller G, Ruiter D, Debruyne F, Schalken J. Molecular genetics and epidemiology of prostate cancer. Endocr Rev 1999; 20:22-45.

3. Motta M, Serio M, editors. Hormonal therapy of prostatic diseases: basic and clinical aspects. Amsterdam: Medicom Europe; 1988.

4. Leewansangtong S, Crawford ED. Maximal androgen withdrawal for prostate cancer therapy: current status and future potential. Endocr-Relat Cancer 1998;5:325-339.

5. Kreis W. Current chemotherapy and future directions in research for the treatment of advanced hormone-refractory prostate cancer. Cancer Invest 1995;13:296-312.

6. Becker-André M, André E, DeLamarter J F. Identification of nuclear receptor mRNAs by RT-PCR amplification of conserved zinc-finger motif sequences. Biochem Biophys Res Commun 1993;194:1371-1379.

7. Carlberg C, Hooft van Huijsduijnen R, Staple J, DeLamarter JF, Becker-André M. RZRs, a novel class of retinoid related orphan receptors that function as both monomers and homodimers. Mol Endocrinol 1994;8:757-770.

8. Giguère V, Tini M, Flock G, Ong E, Evans RM. Isoform-specific amino-terminal domains dictate DNA-binding properties of $\operatorname{ROR} \alpha$, a novel family of orphan homone nuclear receptors. Genes Dev 1994;8:538-553.

9. Becker-André M, Wiesenberg I, Schaeren-Wiemers N, André E, Missbach M, Saurat J-H, Carlberg C. Pineal gland hormone melatonin binds and activates an orphan of the nuclear receptor superfamily. J Biol Chem 1994;269:28531-28534.

10. Hirose T, Smith RJ, Jetten AM. ROR $\gamma$ : the third member of ROR/RZR orphan receptor subfamily that is highly expressed in skeletal muscle. Biochem Biophys Res Commun 1994;205: 1976-1983.

11. Steinmayr M, André E, Conquet F, Rondi-Reig L, DelhayeBouchaud N, Auclair N, Daniel H, Crepel F, Mariani J, Sotelo C, Becker-André M. Staggerer phenotype in retinoid-related orphan receptor $\alpha$-deficient mice. Proc Natl Acad Sci USA 1998;95:3960-3965.

12. Vu-Dac N, Gervois P, Grotzinger T, de Vos P, Schoonjans K, Fruchart JC, Auwerx J, Mariani J, Tedgui A, Staels B. Transcriptional regulation of apolipoprotein A-I gene expression by the nuclear receptor ROR $\alpha$. J Biol Chem 1997;272:2240122404.

13. Schrader M, Danielsson C, Wiesenberg I, Carlberg C. Identification of natural monomeric response elements of the nuclear receptor RZR/ROR: they also bind COUP-TF. J Biol Chem 1996;271:19732-19736.

14. Garcia-Maurino S, Gonzales-Haba MG, Calvo JR, Rafii-ElEdrissi M, Sanchez-Margalet V, Goberna R, Guerrero JM. Melatonin enhances IL-2, IL-6, and IFN- $\gamma$ production by human circulating $\mathrm{CD}^{+}{ }^{+}$cells. J Immunol 1997;159:574-581. 
15. Missbach M, Jagher B, Sigg I, Nayeri S, Carlberg C, Wiesenberg I. Thiazolidine diones, specific ligands of the nuclear receptor retinoid $\mathrm{Z}$ receptor/retinoid acid receptor-related orphan receptor $\alpha$ with potent antiarthritic activity. J Biol Chem 1996;271: 13515-13522.

16. Wiesenberg I, Chiesi M, Missbach M, Spanka C, Pignat W, Carlberg C. Specific activation of the nuclear receptors PPAR $\gamma$ and RORA by the antidiabetic thiazolidinedione BRL 49653 and the antiarthritic thiazolidinedione derivative CGP 52608. Mol Pharmacol 1998;53:1131-1138.

17. Dussault I, Giguère V. Differential regulation of the N-myc proto-oncogene by ROR $\alpha$ and RVR, two orphan members of the superfamily of nuclear hormone receptors. Mol Cell Biol 1997;17:1860-1867.

18. Lee WH, Murphree AL, Benedict WF. Expression and amplification of the $\mathrm{N}-m y c$ gene in primary retinoblastoma. Nature 1984;309:458-460.

19. Schwab M, Ellison J, Busch M, Rosenau W, Varmus HE, Bishop JM. Enhanced expression of the human gene N-myc consequent to amplification of DNA may contribute to malignant progression of neuroblastoma. Proc Natl Acad Sci USA 1984;81:49404944.

20. Nau MM, Brooks BJ Jr, Carney DN, Gazdar AF, Battey JF, Sausville EA, Minna JD. Human small-cell lung cancers show amplification and expression of the N-myc gene. Proc Natl Acad Sci USA 1986;83:1092-1096.

21. Karasek M, Winczyk K, Kunert-Radek J, Wiesenberg I, Pawlikowski M. Antiproliferative effects of melatonin and CGP 52608 on the murine colon 38 adenocarcinoma in vitro and in vivo. Neuroendocr Lett 1998;19:71-78.

22. Hazlerigg DG, Barrett $P$, Hastings MH, Morgan PJ. Are nuclear receptors involved in pituitary responsiveness to melatonin? Mol Cell Endocrinol 1996;123:53-59.

23. Soma MR, Baetta R, De Renzis MR, Mazzini G, Davegna C, Magrassi L, Butti G, Pezzotta S, Paoletti R, Fumagalli R. In vivo enhanced antitumor activity of carmustine [N, $\mathrm{N}^{\prime}$-bis(2-chloroethyl)-N-nitrosurea] by simvastatin. Cancer Res 1995;55:597602 .

24. El-Deiry WS, Tokino T, Velculescu VE, Levy DB, Parsons R, Trent JM, Lin D, Mercer WE, kinzler KW, Vogelstein B. WAF1, a potential mediator of p53 tumor suppression. Cell 1993;75:817825 .

25. Wang J, Chenivesse $X$, Henglein B, Brechot C. Hepatitis B virus integration in a cyclin A gene in a hepatocellular carcinoma. Nature 1990;343:555-559.
26. Ponte P, Ng S-Y, Engel J, Gunning P, Kedes L. Evolutionary conservation in the untranslated regions of actin mRNAs: DNA sequence of a human beta-actin cDNA. Nucleic Acid Res 1984; 12:1687-1696.

27. United Kingdom Co-ordinating Committee on Cancer Research (UKCCCR). United Kingdom co-ordinating committee on cancer research (UKCCCR) guidelines for the welfare of animals in experimental neoplasia (second edition). Br J Cancer 1998;77:1-10.

28. Dunnett CW. A multiple comparison procedure for comparing several treatments with a control. J Am Stat Assoc 1955;50: 1096-1121.

29. Sherr CJ. G1 phase progression: cycling on cue. Cell 1994;79: 551-555.

30. Henglein B, Chenivesse Y, Wang J, Eick D, Brechot C. Structure and cell cycle-regulated transcription of the human cyclin $\mathrm{A}$ gene. Proc Natl Acad Sci USA 1994;91:5490-5494.

31. Wiesenberg I, Missbach M, Carlberg C. The potential role of the transcription factor RZR/ROR as a mediator of nuclear melatonin signaling. Rest Neurol Neurosci 1998;12: 143-150.

32. Koibuchi N, Liu Y, Fukuda H, Takeshita A, Yen PM, Chin WW. ROR $\alpha$ augments thyroid hormone receptor-mediated transcriptional activation. Endocrinology 1999;140:13561364.

33. Baselga J, Norton L, Albanell J, Kim Y-M, Mendelsohn J. Recombinant humanized anti-HER2 antibody (Herceptin ${ }^{\mathrm{TM}}$ ) enhances the antitumor activity of paclitaxel and doxorubicin against HER2/neu overexpressing human breast cancer xenografts. Cancer Res 1998;58:2825-2831.

34. Paravicini G, Steinmayr E, André E, Becker-André M. The metastasis suppressor candidate nucleotide diphosphate kinase NM23 specifically interacts with members of the ROR/RZR nuclear orphan receptor subfamily. Biochem Biophys Res Commun 1996;227:82-87.

35. Wiesenberg I, Missbach M, Kahlen J-P, Schrader M, Carlberg C. Transcriptional activation of the nuclear receptor $R Z R \alpha$ by the pineal gland hormone melatonin and identification of CGP 52608 as a synthetic ligand. Nucleic Acid Res 1995;23: 327-333.

36. Becker-André M, Schaeren-Wiemers N, André E. Correction to the article: [Becker-André, M. et al. Pineal gland hormone melatonin binds and activates an orphan of the nuclear receptor superfamily. J Biol Chem 1994;269:28531-28534]. J Biol Chem 1997;272:16707. 